\title{
Inducement of Flowering in Taniers (Xanthosoma spp) ${ }^{1}$
}

\author{
A. J. Beale, V. E. Green, Jr. and J. L. Parrado ${ }^{2}$
}

\begin{abstract}
Tanier has not been improved through breeding because of a lack of uniform flowering in some clones or a lack of flowering in others. Flowering of taniers was induced by foliar application of gibbereltic acid $\left(\mathrm{GA}_{3}\right)$. One foliar application of $250 \mathrm{p} / \mathrm{m}$ of $\mathrm{GA}_{3}$ applied to 13-week-old plants induced $100 \%$ flowering within 19 weeks; three biweekly applications of $500 \mathrm{p} / \mathrm{m}$ induced $100 \%$ flowering within 15 weeks, and three biweekly applications of $100 \mathrm{p} / \mathrm{m}$ induced $88 \%$ flowering within 21 weeks of the first application. Both the white-fleshed and yellow-fleshed cultivars were induced to flower. More plants flowered, flowered sooner, and produced more flowers per plant when $\mathrm{GA}_{3}$ plus 6-benzyladenine (BA) was used than when $\mathrm{GA}_{3}$ was used alone. Flowers from the treated plants produced much pollen. Applications of $\mathrm{GA}_{3}$ at $250 \mathrm{p} / \mathrm{m}$ or more, either alone or in combination with $B A$, promoted a branching effect on the cormels. The plant shape in all $\mathrm{GA}_{3}$, and $\mathrm{GA}_{3}$ plus $\mathrm{BA}$ treatments was altered. As a result, from three to more than eight auxiliary shoots developed per plant.
\end{abstract}

\section{INTRODUCTION}

Tanier is a staple crop in the American and African tropics (3). The $1977-78$ crop was worth $\$ 12$ million in Florida and $\$ 4.8$ million in Puerto Rico $(9,12)$. Promotion of flowering in tanier is important from a breeding standpoint. Clones differ widely in their traits. Some produce only edible commercial cormels while others produce only edible commercial main corms. Breeding to combine favorable traits of the various clones would result in increased yields. However, if some specific sexual crosses are to be made to produce seeds, some cultivars must be induced to flower. For, although wild cones such as Valery generally flower profusely, some important cultivars do not flower under the environmental conditions of the Caribbean. The clones that flower naturally do not flower uniformly. In addition, a condition of protogyny exists in taniers, making the production of seeds under natural conditions rare. The first report of the production of seeds from a sexual cross was not made until $1975(13,14)$.

Gibberellic acid $\left(\mathrm{GA}_{3}\right)$ has been used to induce the flowering of grasses, tulips, Douglas fir, and Cyclamen persicum $(5,10,11,15)$. Both $\mathrm{GA}_{3}$ and

\footnotetext{
'Submitted to Editorial Board October 15, 1980.

${ }^{2}$ Assistant Agronomist, Agricultural Experiment Station, University of Puerto Rico, Rĩo Piedras, P.R.; Professor (Agronomist), Institute of Food and Agricultural Sciences, University of Florida, Gainesville, Fla; Laboratory Technician, IFAS/UF Agricultural Research and Education Center, University of Florida, Homestead Fla., respectively. This work was supported by the Agricultural Experiment Station of the University of Puerto Rico and the University of Florida and was submitted by the senior author as a portion of his dissertation in partial fulfilment of the requirements for the degree of Doctor of Philosophy. The second author was chairman of his graduate advisory committee.
} 
salicylic acid induced floral buds in Impatiens balsamina (8). Recently, $\mathrm{GA}_{3}$ has been reported to induce flowering in taniers under the climatic conditions of Trinidad $(1,2,6,7)$.

\section{MATERIALS AND METHODS}

One trial and one experiment were conducted to determine the effect of growth regulators on flowering and other plant characters. The growth regulators, their concentrations, and the age of the white-fleshed or of the yellow-fleshed cultivar at the times of treatment applications in the trial and in the experiment are given in tables 1 and 2, respectively.

The trial was planted July 19, 1977, in a Rockdale fine sandy loam, a level phase-limestone complex soil (4) using nonapical main corm sections at a spacing of $91 \mathrm{~cm}$ between rows and $46 \mathrm{~cm}$ within the row. There were 10 plants per plot. The cultivars planted are locally known as Santo Domingo White (white-fleshed) and Malanga Amarilla (Yellow-fleshed). The experiment was planted January 15, 1978, in a Perrine marl soil (4). Apical main corm sections were planted at a spacing of $122 \mathrm{~cm}$ between the rows and $55 \mathrm{~cm}$ within the row. The cultivar used was Santo Domingo White. The plots in the experiment consisted of 10 treatments replicated four times in a randomized complete block design. Each plot was $4.9 \mathrm{~m}$ wide and $5.5 \mathrm{~m}$ long, and consisted of four rows which included 40 plants. Only the center 16 plants in the two middle rows were used for counts and experimental observations.

All growth regulators or chemicals in both the trial and the experiment were applied to the foliage with a hand sprayer pressurized with $\mathrm{CO}_{2}$ gas. In the trial, the growth regulators were applied in $500 \mathrm{ml}$ of water and 1 $\mathrm{ml}$ of wex, a wetting agent. In the experiment, treatments were applied at $2.81 \mathrm{~kg} / \mathrm{cm}^{2}$ pressure in 1 liter of water and in 1 liter of water plus $1 \mathrm{ml}$ of wex per plot.

\section{RESULTS AND DISCUSSION}

In the trial the only treatments that flowered were those including or in excess of $250 \mathrm{p} / \mathrm{m}$ of $\mathrm{GA}_{3}$ or a combination of gibberellin 4 and gibberellin 7 (GA 4/7). By April 3, 1978, 22 weeks after the first application to the trial, all plants in the $250 \mathrm{p} / \mathrm{m}$ or more $\mathrm{GA}_{3}$ or $\mathrm{GA}_{4 / 7}$ treatments were flowering except for treatments 5 and 11 (table 1 ), where $60 \%$ and $50 \%$ of the plants flowered, respectively. The 10 white-fleshed (table 1, treatment 7) and the 10 yellow-fleshed (table 1, treatment 8) plants, which received only one application of $250 \mathrm{p} / \mathrm{m}$ of $\mathrm{GA}_{3}$ were all flowering by June 14, 1978, 19 weeks after treatment application.

Plants which received a combination of $\mathrm{BA}$ plus $\mathrm{GA}_{3}$ appeared more vigorous and formed more flowers per plant than those sprayed with either $\mathrm{GA}_{3}$ or BA. In treatment 6 , the highest $\mathrm{GA}_{3}$ level used, cormel 
TABLE 1.-Foliar growth regulator treatments to young tanier plants

\begin{tabular}{|c|c|c|c|c|c|c|c|}
\hline \multirow{3}{*}{ Treatment No. } & \multirow{3}{*}{ Growth regulator ${ }^{1}$} & \multicolumn{6}{|c|}{ Concentration $-\mathrm{p} / \mathrm{mm}$} \\
\hline & & \multicolumn{6}{|c|}{ Weeks after planting } \\
\hline & & 15 & I8 & 21 & 27 & 28 & 32 \\
\hline 1 & $\mathrm{BA}$ & 10 & 40 & 40 & 40 & 0 & 40 \\
\hline 2 & BA & 250 & 500 & 500 & 500 & 0 & 500 \\
\hline 3 & $\mathrm{BA}+\mathrm{GA}_{3}$ & $10+10$ & $20+20$ & $20+20$ & $20+20$ & 0 & $20+20$ \\
\hline 4 & $\mathrm{BA}+\mathrm{GA}_{3}$ & $250+250$ & $500+500$ & $500+500$ & $500+500$ & 0 & $500+500$ \\
\hline 5 & $\mathrm{GA}_{3}$ & 250 & 500 & 500 & 500 & 0 & 500 \\
\hline 6 & $\mathrm{GA}_{3}$ & 500 & 1000 & 1000 & 1000 & 0 & 1000 \\
\hline 7 & $\mathrm{GA}_{3}$ & 0 & 0 & 0 & 0 & 250 & 0 \\
\hline 8 & $\mathrm{GA}_{3}{ }^{2}$ & 0 & 0 & 0 & 0 & 250 & 0 \\
\hline 9 & AG50X & 0 & 10000 & 10000 & 10000 & 0 & 50000 \\
\hline 10 & AG50Y & 0 & 0 & 0 & 0 & $1.2 \times 10^{6}$ & 0 \\
\hline 11 & $\begin{array}{l}\mathrm{BA}+\mathrm{GA}_{3}+\mathrm{GA} \\
4 / 7+\mathrm{AG} 50 \mathrm{Y}\end{array}$ & 0 & $\begin{array}{l}500+500+ \\
500+10000\end{array}$ & $\begin{array}{l}500+500+ \\
0+10000\end{array}$ & $\begin{array}{l}500+500+ \\
0+10000\end{array}$ & & $\begin{array}{l}500+500+ \\
0+50000\end{array}$ \\
\hline 12 & $\mathrm{GA} 4 / 7$ & 0 & 250 & 0 & 0 & 0 & 0 \\
\hline 13 & Salicylic acid & 1000 & 1000 & 0 & 4000 & 0 & 8000 \\
\hline 14 & Cytex ${ }^{2}$ & 20000 & 20000 & 20000 & 20000 & 0 & 10000 \\
\hline 15 & Maleic hydrazide ${ }^{3}$ & 2800 & 2800 & 2800 & 2800 & 0 & 0 \\
\hline 16 & Maleic hydrazide ${ }^{4}$ & 2800 & 2800 & 2800 & 2800 & 0 & 0 \\
\hline
\end{tabular}

${ }^{1}$ The abbreviations refer to the following compounds: BA, 6-benzyladenine; GA, gibberellic acid; GA 4/7, a mixture of gibberelin 4 and giberellin 7; AG50Y, natural yeast concentrate of 2-ketoacid, cytex to mixed cytokinins (mostly zeatin-like), and maleic hydrazide to 1,2dihydropyridazine-3,6-dione.

${ }^{2}$ Applied to a yellow-fleshed cultivar.

${ }^{3}$ Applied to yellow-fleshed plants stripped of suckers.

${ }^{4}$ Applied to yellow-fleshed plants with several suckers. 
development was affected drastically. Several cormels per plant were initiated, but did not develop. At harvest, after the plants had grown for over 10 months, the average cormel weight was about $10 \mathrm{~g}$ in the highest $\mathrm{GA}_{3}$ level treatment. The cormels did not show malformation except for their reduced size. The plants in the treatment with 250 or more $\mathrm{p} / \mathrm{m}$ $\mathrm{GA}_{3}$ produced a petiole-like bract or bladeless leaf prior to flowering. After flowering, axillary leaf systems began to develop. Tanier leaves in the higher $\mathrm{GA}_{3}$ level turned yellowish-green from the time preceding flowering until harvest.

The salicylic acid-treated plants did not flower. Maleic hydrazide did not prevent suckering of the yellow-fleshed plants which had suckers, or from plants from which the suckers had been removed. Maleic hydrazide noticeably inhibited plant growth at the concentration used. Plants treated with AG50Y appeared no different from the control. Plots with white-fleshed cytex-treated plants appeared no different from the controls, while plots with the yellow-fleshed plants were larger and leafier. Yet the untreated yellow-fleshed plants surrounding the cytex-treated area were better developed than those in the rest of the experimental area, probably because of a more fertile soil.

In the experiment, 15 weeks after the first treatment application the $500 \mathrm{p} / \mathrm{m}$ BA plus $250 \mathrm{p} / \mathrm{m} \mathrm{GA}_{3}$ treatment, and the $1,000 \mathrm{p} / \mathrm{m}$ BA plus 500 $\mathrm{p} / \mathrm{m} \mathrm{GA}_{3}$ treatment produced more bracts and more flowers per plot than the other treatments (table 2). The number of plants with bracts per plot was higher in the 250 or $500 \mathrm{p} / \mathrm{m} \mathrm{GA}_{3}$, in the $500 \mathrm{p} / \mathrm{m}$ BA plus $250 \mathrm{GA}_{3}$, and in the $1,000 \mathrm{p} / \mathrm{m} \mathrm{BA}$ plus $500 \mathrm{p} / \mathrm{m} \mathrm{GA}_{3}$ treatments than in the other treatments. The number of plants with flowers per plot at 15 weeks after the first treatment application was significantly higher in the $500 \mathrm{p} / \mathrm{m}$ $\mathrm{Ga}_{3}$, in the $500 \mathrm{p} / \mathrm{m} \mathrm{BA}$ plus $250 \mathrm{p} / \mathrm{m} \mathrm{GA}_{3}$, and in the $1,000 \mathrm{p} / \mathrm{m}$ BA plus $500 \mathrm{p} / \mathrm{m} \mathrm{GA}_{3}$ treatment than in the other treatments.

Twenty-one weeks after the first treatment, the number of plants flowering per plot was significantly higher in the 250 or $500 \mathrm{p} / \mathrm{m} \mathrm{GA}_{3}$, in the $500 \mathrm{p} / \mathrm{m}$ BA plus $250 \mathrm{p} / \mathrm{m} \mathrm{GA}_{3}$, and in the $1,000 \mathrm{p} / \mathrm{m} \mathrm{BA}$ plus $500 \mathrm{p} /$ $\mathrm{m} \mathrm{GA}_{3}$ treatment than in the other treatments, except for the $100 \mathrm{p} / \mathrm{m}$ $\mathrm{BA}$ plus $100 \mathrm{p} / \mathrm{m} \mathrm{GA}_{3}$ treatment with which there was no difference. The $500 \mathrm{p} / \mathrm{m} \mathrm{GA}_{3}$, the $500 \mathrm{p} / \mathrm{m} \mathrm{BA}$ plus $250 \mathrm{p} / \mathrm{m} \mathrm{BA}_{3}$, and the $1000 \mathrm{p} / \mathrm{m} \mathrm{BA}$ plus $500 \mathrm{p} / \mathrm{m} \mathrm{GA}_{3}$ treatments produced significantly more axillary leaf systems per plant than the other treatments. The $500 \mathrm{p} / \mathrm{m} \mathrm{GA}_{3}$ or the $500 \mathrm{p} / \mathrm{m}$ BA plus $250 \mathrm{p} / \mathrm{m} \mathrm{GA}_{3}$ treatments produced plants with shorter petioles than those in the other treatments, except for the $250 \mathrm{p} / \mathrm{m} \mathrm{GA}_{3}$ and for the $1,000 \mathrm{p} / \mathrm{m} \mathrm{GA}_{3}$ treatments, with which there was no difference.

The results indicate that young tanier plants can be induced to flower by $\mathrm{GA}_{3}$ application. The interval from the time of first application to $100 \%$ flowering was as low as 15 weeks when $\mathrm{GA}_{3}$ was applied at $500 \mathrm{p} / \mathrm{m}$ 
TABLE 2.-Effect of phytohormones on flowering and plant characters

\begin{tabular}{|c|c|c|c|c|c|c|c|c|}
\hline \multirow[t]{3}{*}{ Treatments } & \multirow{3}{*}{$\begin{array}{l}\text { Concentration } \\
p / m\end{array}$} & \multirow{3}{*}{$\begin{array}{l}\text { Bracts/plot }{ }^{1} \\
\text { No. }\end{array}$} & \multirow{3}{*}{$\begin{array}{c}\text { Flowers/plot }{ }^{2} \\
15 \\
\text { No. }\end{array}$} & \multirow{3}{*}{$\begin{array}{l}\text { Plants with } \\
\text { bracts/plot }{ }^{2} \\
\text { Weeks aft } \\
\text { No. }\end{array}$} & \multirow{2}{*}{\multicolumn{2}{|c|}{$\begin{array}{l}\text { Plants with flowers/plot }{ }^{2} \\
\text { st treatment application }\end{array}$}} & \multirow{3}{*}{$\begin{array}{c}\begin{array}{c}\text { Axillary leaf sys- } \\
\text { tems/plant }\end{array} \\
21 \\
\text { No. }\end{array}$} & \multirow{3}{*}{$\begin{array}{r}\begin{array}{r}\text { Petiole } \\
\text { height }\end{array} \\
\mathrm{cm}\end{array}$} \\
\hline & & & & & & & & \\
\hline & & & & & No. & No. & & \\
\hline $\mathrm{BA}$ & 100 & $0 c^{3}$ & $\mathrm{ob}$ & $0 b$ & $0 \mathrm{c}$ & $0 \mathrm{c}$ & $1.4 \mathrm{~d}$ & $111 a b$ \\
\hline $\mathrm{BA}$ & 500 & Ic & $1 \mathrm{~b}$ & $0 \mathrm{~b}$ & $0 c$ & Ic & $1.2 \mathrm{~d}$ & $116 \mathrm{a}$ \\
\hline $\mathrm{BA}$ & 1000 & $0 c$ & $\mathrm{Ob}$ & $\mathrm{ob}$ & $0 \mathrm{c}$ & Ic & $1.2 \mathrm{~d}$ & $113 a b$ \\
\hline $\mathrm{GA}_{3}$ & 100 & $2 \mathrm{c}$ & $1 b$ & Ib & $1 c$ & $14 \mathrm{~b}$ & 2.1bcd & $111 \mathrm{ab}$ \\
\hline $\mathrm{GA}_{3}$ & 250 & $23 \mathrm{~b}$ & $6 \mathrm{~b}$ & $13 a$ & $5 b$ & $16 a$ & $3.6 \mathrm{~b}$ & $107 \mathrm{abc}$ \\
\hline $\mathrm{GA}_{3}$ & 500 & $49 a$ & $19 a$ & $16 a$ & $14 a$ & $16 a$ & $5.5 \mathrm{a}$ & $92 \mathrm{c}$ \\
\hline $\mathrm{BA}$ & 100 & & & & & & & \\
\hline plus $\mathrm{GA}_{3}$ & 100 & $7 c$ & $3 b$ & $3 \mathrm{~b}$ & $2 \mathrm{bc}$ & $15 a b$ & $2.8 \mathrm{bc}$ & $111 \mathrm{ab}$ \\
\hline $\mathrm{BA}$ & 500 & & & & & & & \\
\hline plus $\mathrm{GA}_{3}$ & 250 & $47 a$ & $19 a$ & $15 a$ & $11 a$ & $16 \mathrm{a}$ & $4.8 \mathrm{a}$ & $91 \mathrm{c}$ \\
\hline $\mathrm{BA}$ & 1000 & & & & & & & \\
\hline plus $\mathrm{GA}_{3}{ }^{4}$ & 500 & $47 a$ & $16 \mathrm{a}$ & $15 \mathrm{a}$ & $12 \mathrm{a}$ & $16 a$ & $4.9 a$ & $95 \mathrm{bc}$ \\
\hline Control & 0 & $0 \mathrm{c}$ & $0 b$ & $\mathrm{ob}$ & $0 c$ & $0 c$ & $1.4 \mathrm{~d}$ & $118 a$ \\
\hline
\end{tabular}

${ }^{3}$ Applied at 13,15 , and 17 weeks after planting. The abbreviation BA stands for 6 benzyladenine; $\mathrm{GA}_{3}$ for gibberellic acid.

${ }^{2}$ Sixteen experimental plants per plot.

${ }^{3}$ Means in columns followed by the same letter do not differ significantly at the $5 \%$ probability level according to Duncan's multiple range test.

${ }^{4}$ The third application was $\mathrm{BA}$ at $250 \mathrm{p} / \mathrm{m}$ plus $\mathrm{GA}_{3}$ at $125 \mathrm{p} / \mathrm{m}$. 
in three biweekly applications, to 21 weeks for $88 \%$ flowering when it was applied at $100 \mathrm{p} / \mathrm{m}$ in three biweekly applications. One single application of $\mathrm{GA}_{3}$ at $250 \mathrm{p} / \mathrm{m}$ produced $100 \%$ flowering 19 weeks after application. Generally, more plants flowered, flowered sooner, and produced more flowers per plant when $\mathrm{GA}_{3}$ plus $\mathrm{BA}$ was used than when $\mathrm{GA}_{3}$ was used alone at the same concentration. The flowers from the treated plants produced much pollen.

Although the youngest plants treated in the experiment were 13 weeks old, the same results could probably be obtained with plants 6 to 8 weeks old, or at the 1- to 2-leaf stage. However, unlike the results obtained by Alamu and McDavid (1) in Trinidad, presoaking of the seed pieces (sections or cormels) in solutions of $\mathrm{GA}_{3}$ and planting in flats did not cause the production of flowers in two other trials and three experiments conducted by the authors of this article.

The application of $\mathrm{GA}_{3}$ at $250 \mathrm{p} / \mathrm{m}$ or more, either by itself or in combination with $\mathrm{BA}$, generally promoted cormel malformation. The malformed cormels had one or two characteristics in common. They tended to branch or they tended to elongate or become rhizome-like in form. Tanier cormels are normally mace-shaped, so at present the branched cormels would not be commercially acceptable. However, the cormels from the treated plants in the experiment were larger than those of the control plants.

In the trial, the treatment which included one application of $\mathrm{GA}_{3}$ at $500 \mathrm{p} / \mathrm{m}$ and four applications at $1,000 \mathrm{p} / \mathrm{m}$ prevented initiated cormels from developing. Where lower rates of $\mathrm{GA}_{3}$ were used, cormel malformation occurred. The malformed cormels showed several buds per cormel developing, but they had not reached the branching stage at harvest.

Gibberellic acid affected the plant shape and development. The apical bud turned into a flowering structure. As the flower died, axillary buds began to develop into axillary leaf systems. The higher the concentration of $\mathrm{GA}_{3}$, and especially of $\mathrm{GA}_{3}$ plus $\mathrm{BA}$, the more axillary shoots developed. On the basis of the production of lateral-shoots and of the branching of the secondary cormels, it appears that $\mathrm{GA}_{3}$ acts through a breaking of the apical dominance of the plant.

The practical and immediate significance of the trial and of the experiment is that they open the way for the systematic breeding of tanier. Clones can be forced to flower at the same time. Crosses which were either impossible, or very difficult, to make may now become a reality. The various desirable qualities of the different clones may be combined to improve crop yield and quality. The promotion of flowering would cut the time between planting and flowering, thus allowing for a quicker breeding program than if plants were allowed to flower naturally. Plants could be made to flower in about 21 weeks from planting. 


\section{RESUMEN}

La yautía es una cosecha que forma parte de la dieta diaria de los países tropicales de América y Africa. Aunque existen grandes diferencias en los caracteres de distintas variedades, la yautía no se ha mejorado mediante cruzamiento genético porque los clones no florecen o no florecen uniformemente.

Se determinó que una aplicación de $250 \mathrm{ppm}$ de ácido giberélico a plantas de 13 semanas de edad indujo 100\% de floración a las 19 semanas después de aplicado. Cuando se aplicó tres veces cada dos semanas a 500 ppm se indujo $100 \%$ de floración a las 15 semanas, y cuando se aplicó tres veces a $100 \mathrm{ppm}$, se indujo $88 \%$ de floración a las 21 semanas después de la primera aplicación. Se indjueron a florecer tanto las plantas de carne blanca como las de carne amarilla.

\section{LITERATURE CITED}

1. Alamu, S. and McDavid, C. R. 1978. Effect of time and method of application of gibberellic acid on the growth and promotion of flowering in tannia (Xanthosoma sagittifolium). Trop. Agric. (Trin,) 55(3): 235-41.

2. $\longrightarrow$ and - 1978. Promotion of flowering in edible aroids by gibberellic acid, Trop. Agri. (Trin.) 55(1): 81-6.

3. Coursey, D. G. and Haynes, P. H., 1970. Root crops and their potential as food in the tropics, World Crops 22: 261-65.

4. Gallatin, M. H., Ballard, J. K., Evans, C. B., Galberry, H. S., Hinton, J. J., Powell, D. P., Truett, E., Watts, W. L., and Willson, G. C., 1968. Soil Survey (detailed reconnaissance) of Dade County, Fla, USDA Soil Conservation Sevice and Univ. Fla. Agric. Exp, Stn. Series 1947, No. 4.

5. Kumar, S., Datta K. S., and Narida, K. K., 1977. Gibberellic acid causes flowering in the short-day plants Panicum miliaceum L., P. miliare Lamk., and Setaria italica (L.) P. Beauv., Planta 134(1): 95-96.

6. McDavid, C. R. and Alamu, S., 1976. Promotion of flowering in tannia (Xanthosoma sagittifolium) by gibberellic acid. Trop. Agric. (Trin.) 53(4): 373-74.

7. - and - 1979. Effect of day-length and gibberellic acid on the growth and promotion of flowering in tannia (Xanthosoma sagittifolium), Trop. Agric. (Trin.) 56(1): $17-23$.

8. Narida, K. K., Kumar, S., and Sood, V., 1976. Effect of gibberellic acid and some phenols on flowering of Impatiens balsamina, a qualitative short-day plant, Physiol. Plant. 38:53-6.

9. Puerto Rico Department of Agriculture, 1979. Facts and Figures on Puerto Rico's Agriculture.

10. Ross, S. U. and Pharis, R. P., 1976. Promotion of flowering in the Pinaceae by gibberellins. I. Sexually mature, nonflowering grafts of Douglas fir, Physiol. Plant. 36:182-86.

11. Rudnicki, R. M., Nowak, J., and Saniewshi, M., 1976. The effect of gibberellic acid on sprouting and flowering of some tulip cultivars, Sci, Hortic. 4:387 97.

12. USDA and Florida Department of Agriculture and Consumer Services 1979. Marketing Florida sub-tropical fruits and vegetables, Federal-State Market News Service, Orlando, Fla.

13. Volin, R. B. and Zettler, F. W., 1975. Seed propagation of Xanthosoma caracu (Co" 
coyam) as a potential means of pathogen elimination and genetic improvement, Univ. Fla. Homestead A. R, E. C. Res. Rep. SB 75-1.

14. - and - 1976. Seed propagation of cocoyam, Xanthosoma caracu Koch \& Bouché. Hort. Sci. 11(5): 459—60.

15. Widmer, R. E., Stephen, L. C., and Angell, J. V., 1974. Gibberellin accelerates flowering of Cyclamen persicum Mill. HortScience 9(5):476-77. 